\title{
The untapped industrial crop, Cucumeropsis mannii: dry oil extraction, characterization and potential use as biodiesel feedstock and heavy metal sink
}

Onyeka Stanislaus Okwundu* (D), Chimezie John Chiama, Chinedu James Chiama, Pius Charles Ucheagwu, Ekene Kingsley Uzoma, Chukwujekwu Augustine Okaro and Obiora Ebuka Muojama

\begin{abstract}
Due to the quest to meet a basic need - food, vast potentials of numerous African crops have remained unexplored. Cucumeropsis mannii, an invaluable West African melon, is cultivated for its edible proteinous oil-rich seeds. Here, we report for the first time, its potential use for biodiesel production over an uncommon heterogeneous nanocatalyst, and for wastewater treatment. An identification of the untapped species' seed was made, for disambiguation. Oil (CMO) was expressed from the C. mannii seeds (CMS) and characterized. The CMS was found composed of $53.5 \%$ lipids, while $46.1 \%$ of the full-fat CMS flour was recovered as vegetable oil. Transesterification experiments were performed using a specially-prepared heterogeneous nanocatalyst derived from Eobania vermiculata shells, by varying successively: methanol/oil ratio, temperature, and reaction time. Maximum biodiesel (CMOME) yield of $86.2 \%$ was achieved at catalyst concentration of $5.4 \%$, methanol to oil molar ratio of $9: 1$, reaction temperature of $60^{\circ} \mathrm{C}$, after $3 \mathrm{~h}$ of reaction. Furthermore, part of the polyunsaturated $\mathrm{CMO}$ was sulphur-functionalized and utilized at different dosage levels for extraction of $\mathrm{Ag}^{+}$from 600 to $1500 \mathrm{ppm}$ simulated water. The modified CMO exhibited desirable sorption properties - sinking 100\% of $\mathrm{Ag}^{+}$from $900 \mathrm{ppm}$ water, after 7-h-phase-contact at $6.9 \mathrm{~g}(20 \mathrm{~mL})^{-1}$ dosage. Stagewise operation (multi-staging) was found capable of improving the extraction efficiency in highly concentrated wastewater. Although CMOME conformed to EN-14214 and ASTM D-6751 standards, it had low oxidation stability; making wastewater treatment a more faithful application. Regarding the crop's food value, residual CMS cake remained edible, even with longer shelf-life (relative to the full-fat flour) - encouraging commercial flour-defattening and consequent availability of CMO for industrial applications. Lastly, it was concluded (with some relevant recommendations) that CMO has great potentials for use as biodiesel feedstock and as heavy metal removal agent.
\end{abstract}

Keywords: Egusi, Species identification, Mechanical expression, Melon seed oil, Nutritional value, Snail shell, Nanocatalyst, Transesterification, Water treatment, Liquid-liquid extraction

\footnotetext{
* Correspondence: onyeka.okwundu@eng.uniben.edu

Science and Engineering Unit, Nigerian Young Researchers Academy (NYRA), Onitsha 430231, Anambra State, Nigeria
}

(c) The Author(s). 2021 Open Access This article is licensed under a Creative Commons Attribution 4.0 International License, which permits use, sharing, adaptation, distribution and reproduction in any medium or format, as long as you give appropriate credit to the original author(s) and the source, provide a link to the Creative Commons licence, and indicate if changes were made. The images or other third party material in this article are included in the article's Creative Commons licence, unless indicated otherwise in a credit line to the material. If material is not included in the article's Creative Commons licence and your intended use is not permitted by statutory regulation or exceeds the permitted use, you will need to obtain permission directly from the copyright holder. To view a copy of this licence, visit http://creativecommons.org/licenses/by/4.0/. 


\section{Introduction}

\section{Cucumeropsis mannii (egusi): facts and identity}

From the Cucurbitacean plant family, where the very popular watermelon belongs, comes a white seeded species, C. mannii (or Cucumeropsis edulis [1]), also known as Mann's cucumeropsis or white seed melon - because the seeds are exceptionally white when dehulled. Archeological findings prove it to be one of the major indigenous West African cultigens [2] grown for their proteinous and oil-rich edible seeds.

While all cucurbits may not be popularly referred as melon, Food and Agriculture Organisation (FAO) defines 'melonseed' (documented as item code 299) to include the seeds of all Cucurbitaceae. Based on available statistical data, global production and farmland utilization for melon seed have increased remarkably over the years, as illustrated in Fig. 1a. Hence, much reason to identify 'who is who' in the family. FAO acknowledges Africa as the lead producer of melon seed, with $886 \mathrm{kt}$ accounting for $93 \%$ global production in 2018; and an average annual production of $486 \mathrm{kt}$ accounting for $92 \%$ global production since 1961. Most recent FAO data on global production of melon seed by region together with the top 10 producers is shown in Fig. $1 \mathrm{~b}$ and c [3]. Obviously, Nigeria, 'the giant of Africa' situated in her west, has been controlling and still controls the melon seed market.

(a)

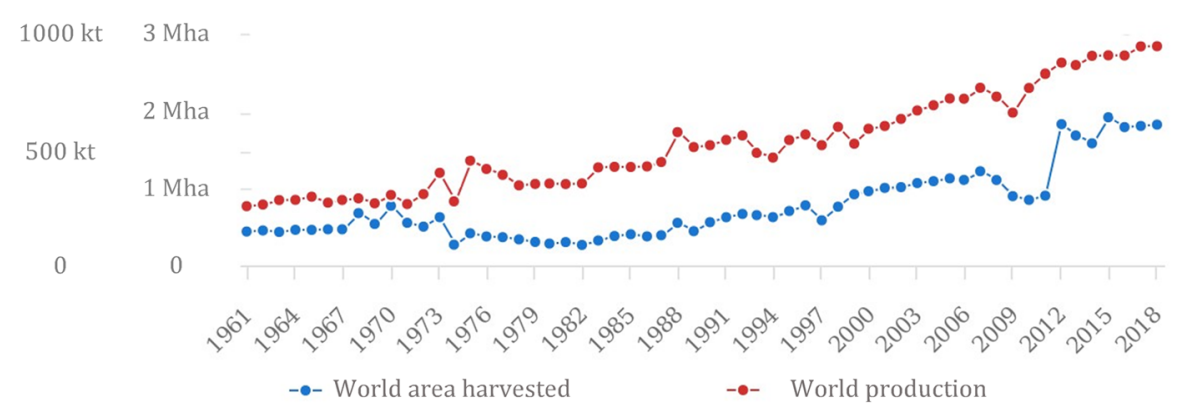

(b)

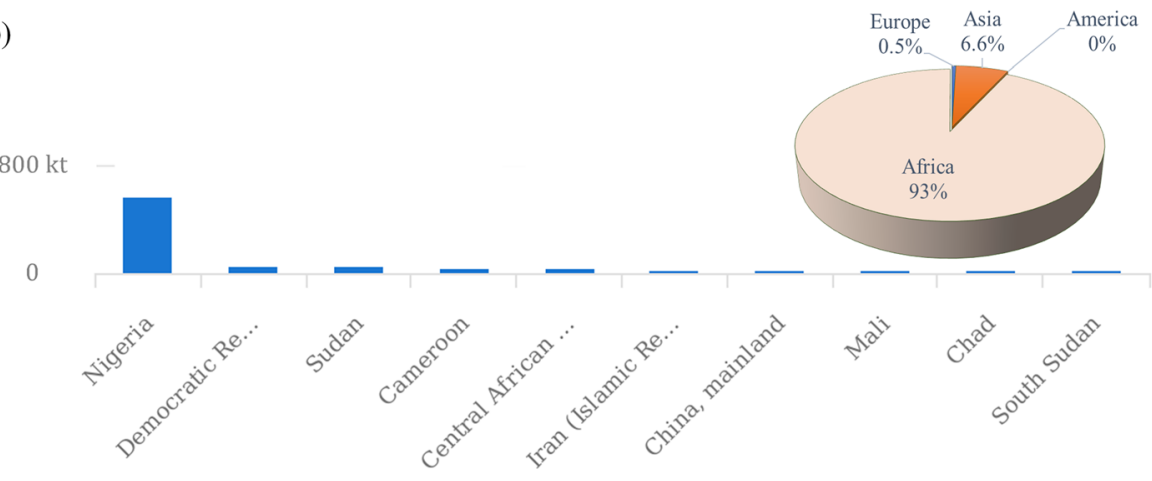

(c)

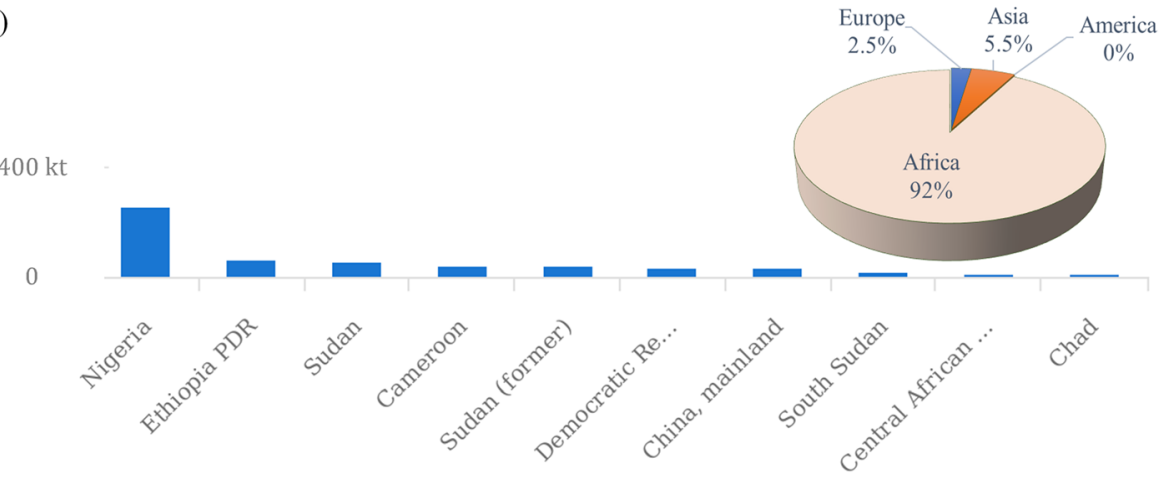

Fig. 1 FAO statistical reports: global production and farmland utilization for melon seed since 1961 (a), most recent (2018) total production (b), and average production from 1961 (c) sorted by region alongside the top 10 countries 
In Nigeria, seeds of $C$. mannii are the major cucurbit seeds produced, mainly for consumption as 'egusi' soup. Etymologically, C. mannii is respectively called: 'agushi', 'egwusi' and 'egusi', according to the 3 major Nigerian tribes: Hausa, Igbo and Yoruba; and that has fetched the crop the generic name 'egusi', even beyond the country. Burkill [4], Essien et al. [5] and Azuaga et al. [6] have acknowledged $C$. mannii as the true 'egusi', while noting the wrong use of egusi-nomenclature for other cucurbits. Yes, it is not amazing that family members do resemble; C. mannii is commonly mistaken for Citrullus spp. (the lanatus, vulgaris or colocynthis [1]) which are wild species of watermelon [7], with black coloration at unshelled seed edges. Egwim et al. [8] noted the Nigerian local names for Citrullus colocynthis and non sounds like 'egusi'. A Cameroon-based study of several cucurbits also identifies C. mannii as 'egusi' melon [9]. However, in the second volume of "Lost Crops of Africa", C. lanatus was treated as 'egusi', while another name, 'egusi-ito' was given to C. mannii; however, the authors admit, "In some West African countries the main egusi crop may be Cucumeropsis mannii" [1]. Also, a seed expert [10] reports, "The particular species we are growing was labeled as Egusi-itoo (C. mannii), but we now believe it to be another Egusi in the same species as watermelon: Citrullus lanatus. The seeds are fat, white, and beautiful, and according to Truelove Seeds apprentice Amirah, who requested we grow this crop, the flesh is the essence of bitterness". Be it as it may, the generally recognized 'egusi' in Nigerian markets is the Cucumeropsis spp.

Lastly, for proper identification, Fig. 2 clearly depicts the distinguishing appearances of the seeds of the two commonly mistaken melon species. Obviously, dehulled C. lanatus seeds are not white. The resemblance of wet C. lanatus seed with watermelon seed is typical of a common species, the Citrullus spp. One good thing irrespective of the misconceived nomenclature is that the cultivation of cucurbits is the same and that is well documented [1, 7]. In essence, the foregoing was never intended to win back egusi-nomenclature for the rightful species, but to aid the reader in identifying the Cucumeropsis spp., which happens to be the subject of this study.

\section{Further background to the study}

Having identified the uncommon source of oil for this study, the C. mannii seed (CMS), what else does one need to know? The use of melon seed in Africa has been limited to food. The seed is usually prepared into snacks or soup, and when the oil is extracted it is still used for food processing [8]. Being edible, melon seed oil is classified as first generation biomass and arguably should be reserved for food [13]. However, considering the attractive tolerance for wide range of climatic conditions [1], short life cycle (4 to 5 months, from sowing to harvest) [7], ease of cultivation [7], high oil content (about 50\% of dehulled seed on dry basis), and the fact that melon seed cake remains edible after oil extraction; melon seed
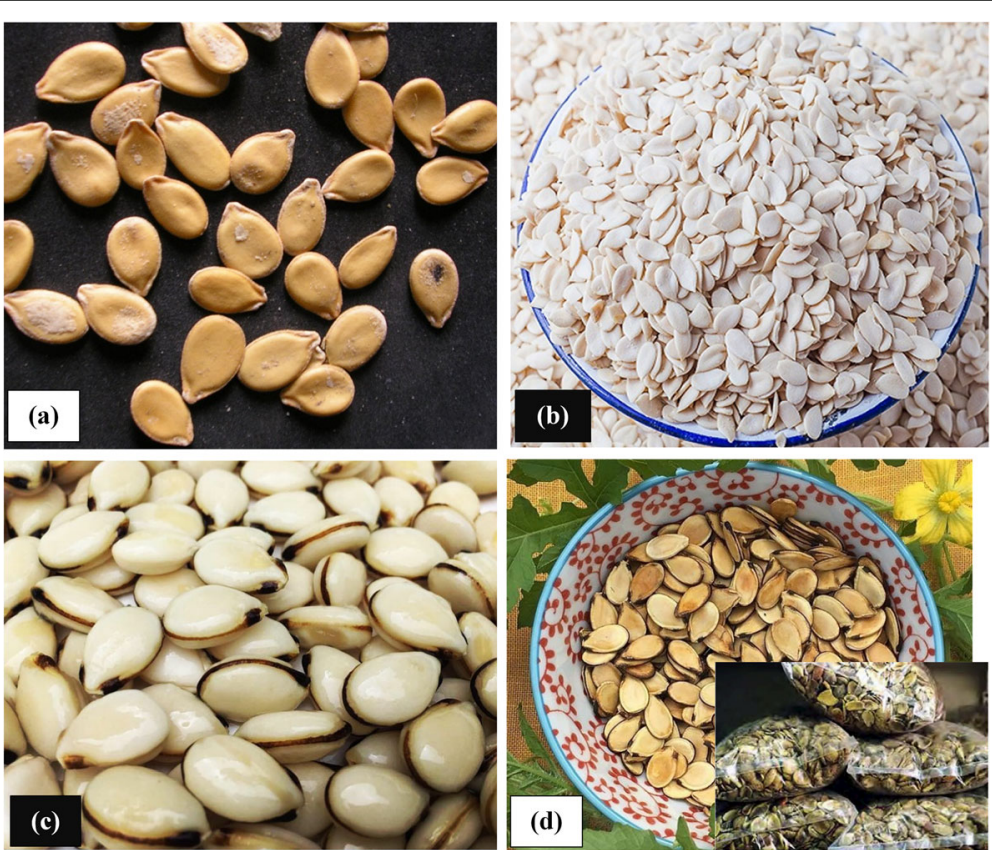

Fig. 2 Distinguishing appearances of the seeds of the two commonly mistaken melon species: a Unshelled Cucumeropsis mannii seeds [11], b Dehulled C. mannii seeds [12], c Wet unshelled Citrullus lanatus seeds, and d Dried unshelled (in plate) [10] and dehulled (in bags) [1] C. lanatus seeds 
oil could reasonably serve as feedstock to the chemical industry, without much disruption to the existing foodchain.

Notably, one common ill-practice in food processing researches is the extraction (leaching) of edible oils with undrinkable solvents like ether and hexane or the likes of benzene and toluene (aromatic hydrocarbons); this renders both the oil extract and the resulting cake unhealthy for consumption. Characterization of or further research on such extracts or their cakes would certainly not represent the healthy processing encouraged in food industries. Opoku-Boahen et al. [14] characterized $C$. colocynthis and C. manni oils extracted using petroleum ether, for cooking purpose in Ghana. Also, in the assessment of food qualities of defatted C. mannii cake, Ogunbusola et al. [15] extracted oil using n-hexane. In addition, cold maceration with $\mathrm{n}$-hexane has been tried [6]. While on the healthy side, C. lanatus oil has been extracted using supercritical carbon dioxide [16], and with water [8]. Also, the effect of operating conditions on the mechanical expression of oil from Citrullus vulgaris has been studied [17]. However, studies on the extraction and characterization of C. mannii oil (CMO) in a manner appropriate for food processing and the effect of defatting melon seed flour on the flour's shelf-life, are barely documented.

Apart from food, research has shown that various varieties of melon seed could yield vegetable oils suitable for biodiesel production. Biodiesel is a promising renewable alternative to fossil diesel, which meets certain regulatory standard, produced by reacting lipids with low molecular weight alcohols usually in the range of $C_{1}$ to $\mathrm{C}_{4}$. While fats and oils are combustible, they are not suited for direct use in conventional combustion ignition engines due to their high viscosity which results in poor fuel atomization and deposition of carbon particles on the engine (coking). Among the several techniques developed to reduce the viscosity of lipid feedstock, transesterification is the most mature, and it is strictly the only means to producing what can be termed biodiesel [13]. Biodiesel with acceptable qualities have been produced from C. lanatus oil [18], and C. colocynthis [19]. Opoku-Boahen and co-workers [20] investigated the use of $\mathrm{CMO}$ as potential biodiesel feedstock but they report an outrageous kinematic viscosity value of $15 \mathrm{~mm}^{2} \mathrm{~s}^{-1}$ for the biofuel - ASTM and European standards stipulate maximum viscosities of 6.0 and $5.0 \mathrm{~mm}^{2} \mathrm{~s}^{-1}$, respectively. Moreover, investigations on the potential use of melon seed oil as biodiesel feedstock, are limited to transesterification by homogenous catalysis; typically employing the likes of $\mathrm{H}_{2} \mathrm{SO}_{4}$ [20], $\mathrm{KOH}$ [18], and $\mathrm{NaOCH}_{3}[19]$, as catalysts.

Furthermore, another possible applicability of melon seed oil is in wastewater treatment. Heavy metal remediation by membrane separation, adsorption, or extraction can be enhanced by respectively functionalizing the membrane, adsorbent, or extracting solvent, with sulphur-containing group, such as the thiol-moiety. This is because sulphur-containing moieties have shown strong affinity for heavy metal ions [21-26]. Murray et al. [23] patented the extractive sequestration of heavy metals from heavy metal-contaminated solid, liquid or gaseous materials, by treating such matter with thiolfunctionalized fatty acids or thiol-functionalized lipids. Since the discovery, only sulphur-modified canola and corn oils have been tried [23, 24, 27]. Based on our recent comparative study of sorption potentials of thiolated oils with different levels of fatty acid unsaturation, derived from Elaeis guineensis and Glycine max, high level of unsaturation was found desirable [28], and studies have shown $\mathrm{CMO}$ to be of high iodine and peroxide values [20], suggesting good candidacy of thiolated $\mathrm{CMO}$ as heavy metal sink in wastewater treatment application. Meanwhile, the choice of Ag as contaminant is well justified [28].

Altogether, this study investigates the potentials of mechanically expressed and characterized $\mathrm{CMO}$, as biodiesel feedstock and as heavy metal sink, without neglecting the food value of CMS. The uncommon use of heterogeneous catalyst in melon seed oil transesterification, is investigated. And for the first time, the use of $\mathrm{CMO}$ as heavy metal removal agent, for treating contaminated water, is reported. Food qualities of defatted and full-fat CMS flour samples were also probed over a long duration of storage, to ascertain their shelf lives in the absence of food additives/preservatives.

\section{Experimental}

\section{C. mannii fruit processing for seeds, preparation of CMS} flour and mechanical expression of CMO

Five matured $C$. mannii fruits were purchased from local farmers in Anam, Anambra State, Nigeria. Sequestration of the C. mannii seeds from the solid pulp of the fruit was achieved by bursting the fruit open using the blunt edge of a hard object - sharp edges could cut through and slice some of the seeds, and shallowly burying the fruit content (pulp and seed) in soil for $6 \mathrm{~d}$ to enable the pulp content to rot. The seeds were recovered from rotten pulp by washing and screening [7]. The recovered fragile unshelled seeds were sun-dried for a day to reduce the moisture content and improve resistance to shear stress (to reduce seed breakage during dehulling). The seeds were dehulled manually and further sun-dried for a day.

Dehulled seeds were finely comminuted using Rose GTM-8302 milling system. Prior to oil expression, part of the resultant full-fat CMS flour was removed for characterization and the rest was heated in the oven at 
$130{ }^{\circ} \mathrm{C}$ for $20 \mathrm{~min}$ [17]. The heated full-fat CMS flour was instantly wrapped in a sieve cloth and squeezed in a mechanical screw press to derive CMO. The full-fat flour and the resulting defatted flour samples were further examined for food qualities. Percentage oil recovery - an important parameter usually conceived as oil yield in most extraction literature - was calculated as expressed in Eq. (1).

$$
\begin{aligned}
& \text { Percentage oil recovery }(\%) \\
& =\frac{\text { Amount of oil extracted }}{\times 100} \text { Amount of full - fat flour used for extraction }
\end{aligned}
$$

\section{Characterization of CMO, full-fat CMS flour and defatted CMS flour samples}

While the amount of mechanically expressed oil per unit mass of the heated full-fat CMS flour was noted, the acid value (AV), kinematic viscosity, saponification value (SV), iodine value (IV), specific gravity, flash point, fire point, and fatty acid profile of the oil were determined as described elsewhere [13]. Also, the cetane index and high heating value (HHV) of the oil were calculated according to the models (Eqs. (2) and (3)) developed by Krisnangkura [29] and Demirbas [30], respectively.

$$
\begin{aligned}
& \text { Cetane index }=46.3+\frac{5458}{S V}-0.225(I V) \\
& H H V\left(\mathrm{~kJ} \mathrm{~g}^{-1}\right)=49.43-[0.041(\mathrm{SV})+0.015(\mathrm{IV})]
\end{aligned}
$$

Furthermore, the freshly produced full-fat CMS flour and defatted CMS flour samples were examined for nutritional content via proximate analysis [31]. They were then tied in black thin polyethylene bags, and stored under ambient condition (about $28^{\circ} \mathrm{C}$ ). Both flour samples were assessed every 2 days for rancidity via ultraviolet (UV) absorption and sensory analysis. In order to probe rancidity by UV absorption, $1 \mathrm{~g}$ of the full-fat flour or $3.8 \mathrm{~g}$ of the defatted flour was stirred with $20 \mathrm{~mL}$ of iso-octane and the homogeneous liquid extract phase basically composed of iso-octane and oil [32], was recovered by centrifugation at $6000 \mathrm{rpm}$. HITACHI UV Spectrophotometer (U-3900) was used to analyze the extract phase at the wavelength range of 220 to $380 \mathrm{~nm}$. Bearing in mind that UV absorption increases with increasing levels of oxygen uptake and peroxide formation, and that the magnitude of UV absorbance is not readily related to the amount of oxidation [33]; this test was only used qualitatively to detect relative changes in CMO oxidation levels. The sensory analysis considered the organoleptic taste and smell of the samples [31]. At the onset and end of the probation period, the peroxide value [33] and AV of CMO samples (extracted using ethyl ether by Soxhlet method, from the flour samples), were each determined for more reliable quantitative assessment.

\section{Preparation and characterization of heterogeneous transesterification catalyst}

Helical shells of an Egyptian desert snail species (E. vermiculata) were picked from remote corners of Borg El'Arab region of Alexandria, Egypt. They were sorted, washed and decalcified without comminution. The solid shells were gradually added to $1 \mathrm{M}$ aqueous sulphuric acid with continuous mild stirring to achieve decalcification; shell disintegration was simultaneously followed by effervescence (release of $\mathrm{CO}_{2}$ ), as represented in Eq. (4). The volume of used acid solution was such that the shells just get completely dissolved. The resultant solution was filtered through Whatman filter paper, under vacuum, using Buchner flask and funnel. Caustic solution $(1 \mathrm{M} \mathrm{NaOH})$ was added in drops to the clear filtrate, in order to precipitate calcium hydroxide as represented by Eq. (5). Precipitated hydroxide was recovered by filtration as before, and washed repeatedly with distilled water. The washed precipitate was oven-dried overnight, at $100^{\circ} \mathrm{C}$, and mortar-crushed to powder. In order to derive an active basic catalyst, the resultant powdered hydroxide was calcined at $500^{\circ} \mathrm{C}$ in muffle furnace (Eq. (6)), and stored air-tight [13]. In a nutshell, Fig. 3 demonstrates the catalyst preparation protocol.

$$
\begin{aligned}
& \mathrm{CaCO}_{3(\mathrm{~s})}+\mathrm{H}_{2} \mathrm{SO}_{4(\text { aq) }} \rightarrow \mathrm{CaSO}_{4(\mathrm{aq})}+\mathrm{H}_{2} \mathrm{O}+\mathrm{CO}_{2}(\mathrm{~g}) \\
& \mathrm{CaSO}_{4(\mathrm{aq})}+2 \mathrm{NaOH}_{(\mathrm{aq})} \rightarrow \mathrm{Ca}(\mathrm{OH})_{2(\mathrm{~s})}+\mathrm{Na}_{2} \mathrm{SO}_{4} \text { (aq) } \\
& \mathrm{Ca}(\mathrm{OH})_{2}+\mathrm{Heat} \leftrightarrow \mathrm{CaO}+\mathrm{H}_{2} \mathrm{O}
\end{aligned}
$$

Afterwards, the material was characterized by: scanning electron microscopy (SEM), transmission electron microscopy $(T E M)$, surface area analysis $(B E T), X$-ray diffraction (XRD), X-ray fluorescence $(X R F)$ and particle size analyses, using: JEOL JSM-6010LV, JEOL JEM2100F, Belsorp II (BEL Japan), Shimadzu Xlab 6100, Rigaku NEX CGEDXRF, and Malvern Zetasizer, respectively. Some characteristic features of the snail shellderived catalyst are shown in Fig. 4. A pictorial view of the precipitated bulk powder before and after calcination, as well as a scanning electron micrograph showing the catalyst's porous surface structure and morphology, are respectively shown in Fig. 4a and b. The transmission electron micrograph (Fig. 4c) reveals that the 


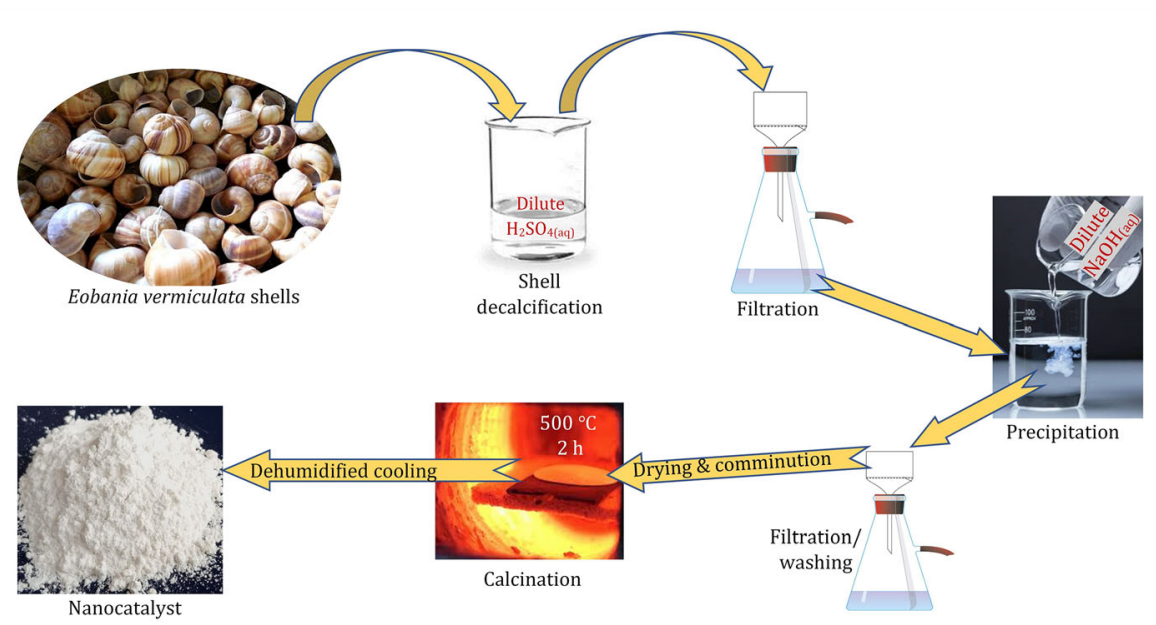

Fig. 3 Schematic demonstration of the shell decalcification-precipitation-calcination route for the nanocatalyst preparation

particles were well within the nano range, while the XRD spectrum (Fig. 4d) is typical of $\mathrm{CaO}$ crystal. The crystal fingerprint of the synthesized catalyst was identified by matching the XRD peaks with standard data, the Joint Committee on Powder Diffraction Standards: JCPDS file No. 017-0912 (for CaO), and JCPDS No. 01073-5492 [for $\left.\mathrm{Ca}(\mathrm{OH})_{2}\right]$, as identified in Fig. 4d. The $\mathrm{CaO}$ crystal grain size (based on Debye-Scherrer model) was $31.0 \mathrm{~nm}$. Hydration of $\mathrm{CaO}$, upon exposure to atmospheric moisture, in the course of sampling, could be responsible for the observed minor hydroxide peaks at $2 \theta=34.3$ and $51^{\circ}[34,35]$. The composition was justified by the $99.3 \% \mathrm{CaO}$ content gotten from XRF analysis. An average particle size of $87 \mathrm{~nm}$ was obtained from particle size analysis with a polydispersity index of 0.22 , while BET analysis showed material surface area of $5.1 \mathrm{~m}^{2} \mathrm{~g}^{-1}$. This shell decalcification-precipitation-calcination route was employed to minimize electric energy consumption - direct calcination of shells requires higher calcination (a)
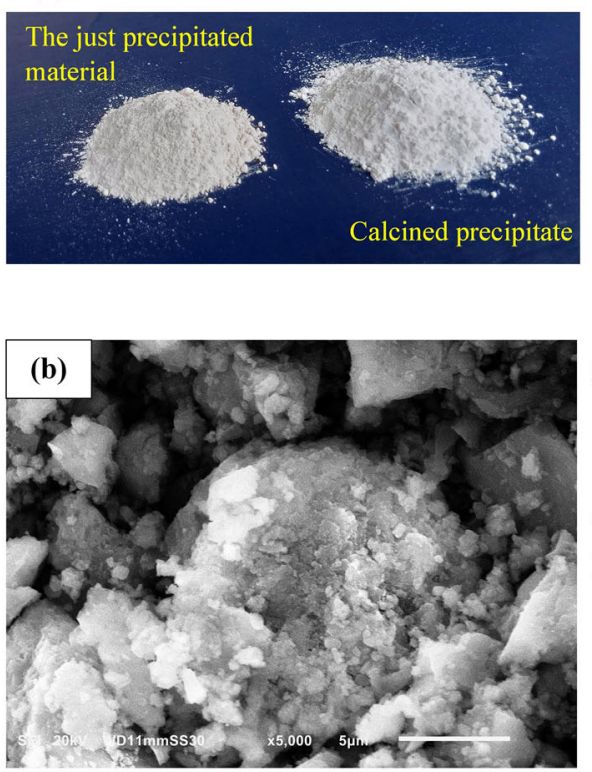

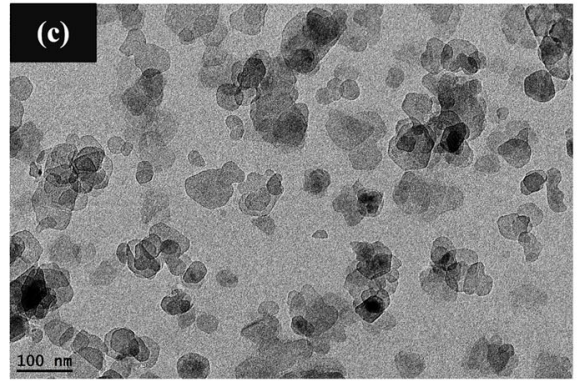

(d)

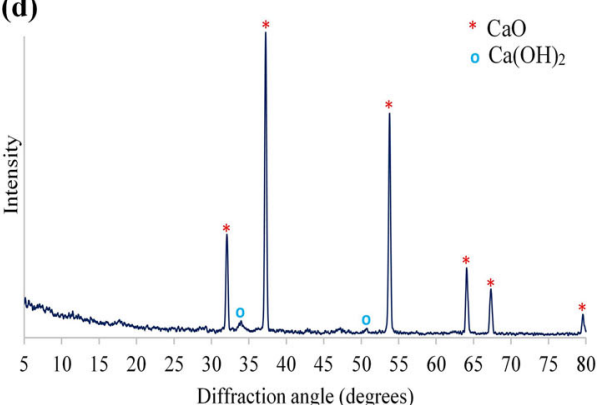

Fig. 4 Characteristic features of the snail shell-derived catalyst: a image of the just-precipitated material after crushing to powder (left) and the calcined precipitate or catalyst (taken by TECNO Pouvoir 3 Plus), b SEM image of the catalyst, c TEM image of the catalyst, and $\mathbf{d}$ XRD spectrum of the catalyst 
temperatures and therefore consumes more energy. Moreover, it guarantees material purity.

\section{Biodiesel production experiments}

The CMO had very low free fatty acid (FFA) content as depicted by the AV $\left(<2 \mathrm{mg} \mathrm{KOH} \mathrm{g}^{-1}\right.$ of oil); therefore, there was no need for acid catalyzed pretreatment prior to transesterification [36]. Part of the CMO was transesterified with methanol (99.8\%; product of JHD) in different experimental runs, using identical batch continuously stirred tank reactors (sealed $500 \mathrm{~mL}$ round-bottom flask, immersed in a water bath mounted over HJ-4A Thermostatic Dual Control Constant Magnetic Agitator Hotplate).

Using $100 \mathrm{~g}$ of the oil in every experimental run, a catalyst concentration of $5.4 \%$ was adopted throughout this study [37]. In a typical experimental run, oil was weighed into the reactor and preheated to the desired reaction temperature, while suitable amounts of the nanocatalyst and methanol were measured, covered and premixed for $20 \mathrm{~min}$. Premixed methanol-catalyst mixture was carefully emptied into the preheated oil, and the reactor was set up with stirring and temperature controls. Stirring was initiated as soon as the catalystmethanol mixture was added and timing started instantly. The methanol to oil molar ratio (3 to 15), temperature $\left(30\right.$ to $65^{\circ} \mathrm{C}$ ), and reaction time (1.5 to 3.5 $\mathrm{h}$ ), were varied one after the other, in order to determine the optimum biodiesel yield; median values of the latter process factors were used prior to their optimization. After transesterification, the outlined biodiesel recovery procedure, characterization procedures and objective yield model by Okwundu et al. [38] were adopted. All experimental runs were performed in duplicate and mean results were reported. Only the biodiesel sample with the best yield was characterized; therefore, production at optimum condition was repeated to obtain adequate amount of the sample for characterization.

The resultant biofuel was assessed for ester content, AV, density, saponification value, IV, cetane index, high heating value, kinematic viscosity, water content, cold filter plugging point (CFPP), cloud point, pour point, flash point, and fire point, as described elsewhere [13].

\section{Liquid-liquid extraction studies}

Part of the remaining CMO was modified by reacting with excess 1-heptanethiol under UV light (wavelength of $300 \mathrm{~nm}$ ) such that it becomes thioether functionalized (TF) [39]. In a typical modification experiment, $100 \mathrm{~g}$ of $\mathrm{CMO}$ was reacted with $65 \mathrm{~g}$ of heptanethiol to obtain crude TF-CMO. Thereafter, the modified oil (TF-CMO) sample was recovered from its crude mixture with excess/unreacted heptanethiol, by simple distillation.

Afterwards, $\mathrm{AgNO}_{3}$, a product of Sigma Aldrich, was used to simulate deionized water, giving 600, 900, 1200 and $1500 \mathrm{ppm}$ stock solutions. Cation extraction experiments were carried out using $20 \mathrm{~mL}$ of the contaminated water per run. At first, equilibrium liquid-liquid contact time was determined by adding roughly $3.5 \mathrm{~g}$ of the TF$\mathrm{CMO}$ to $20 \mathrm{~mL}$ of contaminated water in masked (lightproofed) conical flask, mounted on a stirrer. Considering the light sensitivity of silver salts, the whole experimental set-up was within an enclosed dark chamber. In each case, the two phases were contacted by stirring at $200 \mathrm{rpm}$ for up to $10 \mathrm{~h}$, at room temperature $\left(28^{\circ} \mathrm{C}\right)$. In the interim of stirring, samples were taken after: $0.5,1,2,4,6,8$ and 10 $\mathrm{h}$, and separated. Treated water samples were collected from the clear aqueous layer recovered by centrifugation of the stirred oil-water mixture, for analysis. In order to examine the influence of sulphur-modification of $\mathrm{CMO}$, unmodified $\mathrm{CMO}$ was used in control experiments, at the extreme concentrations of the contaminant (600 and $1500 \mathrm{ppm}$ ). Inductively Coupled Plasma Mass Spectrometer (ICPMS-2030 Shimadzu) was used to analyze the water samples, at $328 \mathrm{~nm}$ [24], while a commercial standard Ag solution (QMX Laboratories Ltd., UK) was used for calibration. The efficiency of the sorption process was calculated using Eq. (7a); Where: $\left[\mathrm{Ag}^{+}\right]_{0}$ and $\left[\mathrm{Ag}^{+}\right]_{t}$ are the initial and instantaneous concentrations of the metallic ion in water.

$$
\text { Sorption efficiency }(\%)=\frac{\left[\mathrm{Ag}^{+}\right]_{0}-\left[\mathrm{Ag}^{+}\right]_{t}}{\left[\mathrm{Ag}^{+}\right]_{0}} \times 100
$$

Lastly, varied concentrations of the extractant (from 0.1 to $10 \mathrm{~g}$ per $20 \mathrm{~mL}$ of water) were tried in order to investigate the sorption capacities of TF-CMO in the simulated stock solutions. This time around, stirring lasted for the determined period of time necessary for phase equilibrium to be achieved. Separation and analysis of treated water were performed as earlier stated. In this case however, $\mathrm{Ag}^{+}$sorption efficiency was calculated according to Eq. (7b). Where: $\left[\mathrm{Ag}^{+}\right]_{e q}$ is the equilibrium concentration of the metallic ion in water.

$$
\text { Sorption efficiency }(\%)=\frac{\left[\mathrm{Ag}^{+}\right]_{0}-\left[\mathrm{Ag}^{+}\right]_{e q}}{\left[\mathrm{Ag}^{+}\right]_{0}} \times 100
$$

\section{Results and discussion}

\section{CMO extraction and characterization results}

Upon mechanical expression using screw press, $460.83 \mathrm{~g}$ of CMO was derived from $1 \mathrm{~kg}$ of full fat CMS flour. This oil recovery of $46.1 \%$ is well above the range obtained by Ajibola et al. [17], who report maximum recovery of $41.6 \%$ for the expression of vegetable oil from seeds of C. vulgaris having $51 \%$ oil content, under similar extraction conditions employed in this study. Physicochemical properties of $\mathrm{CMO}$ obtained in this study, alongside those from literature, are given in Table 1. The higher lipid 
content of full-fat CMS used in this study, as would be shown later, could be accountable for the higher oil recovery. The resulting yellowish viscous liquid at room temperature, identified as $\mathrm{CMO}$, had very low acid value < $2 \mathrm{mg} \mathrm{KOH} \mathrm{g}{ }^{-1}$, and therefore required no pretreatment step prior to transesterification for biodiesel production [13, 38]. The IV was quite high - suggesting high degree of fatty acid unsaturation. The recovered oil had $1.1 \%$ free moisture and relatively low viscosity $\left(32 \mathrm{~mm}^{2} \mathrm{~s}^{-1}\right)$ in comparison with the works of Essien et al. [5] and Azuaga et al. [6]. Considering its fuel properties, the CMO had low cetane index (a value of 46.9) compared to the 63.7 reported for beef tallow feedstock, elsewhere [13]. However, the HHV $\left(40 \mathrm{~kJ} \mathrm{~g}^{-1}\right)$ falls within the vegetable oil range: 37 to $41 \mathrm{~kJ}$ $\mathrm{g}^{-1}$ [30]. Due to the molecular triglyceride chain branching in lipids, transesterification of lipids improves the cetane index. Notwithstanding, according to ASTM D-6751, the viscosity needs to be less than $6 \mathrm{~mm}^{2} \mathrm{~s}^{-1}$, for the flammable liquid to be employed as fuel in a normal diesel engine, in order to minimize fuel atomization and coking problems noted earlier.

Furthermore, the fatty acid profile from GC/MS analysis shows that more than $80 \%$ of the fatty acid molecules in the $\mathrm{CMO}$ were unsaturated (17.5\% monounsaturated oleic acid and $63.6 \%$ polyunsaturated linoleic acid). Unsaturated fats are nutritionally desirable and may possibly lower blood cholesterol level when consumed [17, 38]; but the attractive food value of CMO should not completely limit its industrial potential. The high fatty acid unsaturation suggests the reactivity of $\mathrm{CMO}$ - its amenability to sulphur-functionalization [24]. The IV $>100 \mathrm{~g} \mathrm{I}_{2}(100 \mathrm{~g})^{-1}$ suggests that $\mathrm{CMO}$ is a drying oil and would therefore be suitable for ink and paint production [41]. Differences in CMS cultivar and cultivation practices, age of oil (starting from the time the melon fruits were processed/harvested), and extraction technique, could have contributed to the slight diversity in AV and fatty acid profile shown in Table 1. Efthymiopoulos et al. [32] report wide variation in FFA content for oil samples extracted using various polar and non-polar solvents, and for both the titration and nuclear magnetic resonance means of measuring FFA content. Note that FFA content is approximately half of AV (even though they have different units). This study employed dry expression of oil rather than leaching with solvent, and $\mathrm{AV}$ was determined by titrimetric technique.

\section{Qualities of full-fat and defatted CMS flour samples}

Proximate analysis of both the full-fat and defatted CMS flour samples revealed the nutritional compositions shown in Table 2. The act of heating the full fat flour prior to expression, contributed significantly to reduction in moisture content: from $6.2 \%$ in full-fat flour to 2.7 and $1.1 \%$ in the resultant cake and oil, respectively. Of course, such reduction in moisture content would directly enhance

Table 1 Physicochemical properties of $\mathrm{CMO}$

\begin{tabular}{|c|c|c|c|c|c|}
\hline & This study & {$[20]$} & [14] & {$[5]$} & {$[6]$} \\
\hline Medium of extraction & Dry $^{A}$ & Ether ${ }^{B}$ & Ether ${ }^{B}$ & Ether ${ }^{B}$ & n-hexane ${ }^{c}$ \\
\hline Recovery (\% of full-fat flour) & 46.1 & & 28.82 & 57.26 & 19.92 \\
\hline Colour & Yellowish* & & & Pale yellow & Golden yellow \\
\hline Acid value ( $\mathrm{mg} \mathrm{KOH} \mathrm{g}^{-1}$ ) & 0.93 & 6.89 & 1.43 & 7.09 & 2.40 \\
\hline Saponification value (mg KOH g${ }^{-1}$ ) & 179.4 & 187.23 & 188.96 & 220.19 & 168.3 \\
\hline lodine value $\left[\mathrm{g} \mathrm{I}_{2}(100 \mathrm{~g})^{-1}\right]$ & 132.6 & 128.49 & 106.13 & 114.94 & 1.17 \\
\hline Moisture content (wt\%) & 1.09 & & & 27.30 & 0.16 \\
\hline Specific gravity & $0.9162^{* *}$ & 0.9158 & 0.9162 & 0.9129 & 0.9000 \\
\hline Kinematic viscosity $\left(\mathrm{mm}^{2} \mathrm{~s}^{-1}\right)$ & $31.6^{* *}$ & & & 6451.97 & 53.33 \\
\hline Cetane index & 46.9 & & & & \\
\hline $\mathrm{HHV}\left(\mathrm{KJ} \mathrm{g}^{-1}\right)$ & 40.1 & & & & \\
\hline Flash point $\left({ }^{\circ} \mathrm{C}\right)$ & 320 & & & & \\
\hline Fire point $\left({ }^{\circ} \mathrm{C}\right)$ & 353 & & & & \\
\hline \multicolumn{6}{|l|}{ Fatty acid profile } \\
\hline Palmitic acid, C16:0 (\%) & 9.8 & 11.5 & & 10.57 & \\
\hline Stearic acid, C18:0 (\%) & 9.0 & 14.1 & & 8.33 & \\
\hline Oleic acid, C18:1 (\%) & 17.5 & 15.5 & & 13.65 & \\
\hline Linoleic acid, C18:2 (\%) & 63.6 & 58.8 & & 62.14 & \\
\hline Linolenic acid, C18:3 (\%) & & & & 5.29 & \\
\hline
\end{tabular}

A mechanical expression technique; ${ }^{\text {B }}$ Soxhlet extraction method; ${ }^{C}$ Cold maceration; ${ }^{*}$ Microsoft colour RGB $=245-200-20$ (according to associated MethodsX); ${ }^{* *}$ analysis was performed at $28^{\circ} \mathrm{C}$ 
Table 2 Nutritional compositions of full-fat and defatted CMS flour samples

\begin{tabular}{lcccccc}
\hline & Moisture & Ash & $\begin{array}{c}\text { Lipid } \\
\text { moisture-free basis }\end{array}$ & $\begin{array}{c}\text { Fibre } \\
\text { brotein }\end{array}$ & Carbohydrate \\
\hline $\begin{array}{l}\text { Full-fat } \\
\text { flour (\%) }\end{array}$ & 6.2 & 2.7 & 53.5 & 1.0 & 38.2 & 4.6 \\
$\begin{array}{l}\text { Defatted } \\
\text { flour (\%) }\end{array}$ & 2.7 & 3.9 & 9.9 & 2.5 & 74.8 & 8.9 \\
\hline
\end{tabular}

accessibility of oil through the intra- and inter-particle pores of CMS flour during expression, thereby leading to much appreciable recovery. Effectiveness of the expression process was marked by drastic drop in oil content of the CMS flour: from 53.5 to $9.9 \%$. Considering the composition of the residual cake (defatted CMS flour sample), one could safely consider it as a mere piece of protein. Such piece could invaluably serve as dietary protein and may be used to supplement food protein in the fortification of such foods like those made of cassava [31, 42]. The nutritional contents of full-fat CMS flour reported in Table 2 is quite comparable with those of "five species of egusi seeds" (including C. mannii) examined by Fokou et al. [9], while the alteration (increase) in ash, fibre, protein and carbohydrate contents observed after defatting the flour is very normal resulting from normalization of values after significant drop in lipid content.

In addition, the rancidity tests: UV light absorption and sensory probation of the flour samples, were used to detect incipient rancidity. Maximum UV absorption was observed at $290 \mathrm{~nm}$; therefore, all absorbance measurements were taken at this wavelength. The UV absorbance of the full-fat-flour iso-octane extract phase increased steadily from 0.31 (on the 1st day) to 0.77 (on the 7th day); but on the 9th day, a sharp rise in absorbance up to 1.39 was observed. The taste and smell of the full-fat flour became completely off on the 13th day; As at then, the absorbance was 2.4. Beyond $2 \mathrm{wk}$. of storage, growth of mold began to set-in. Peroxide value increased from 1.8 meq $\mathrm{O}_{2} \mathrm{~kg}^{-1}$ on the 1st day, to $23.7 \mathrm{meq} \mathrm{O}_{2}$ $\mathrm{kg}^{-1}$ on the 9th day, for CMO samples extracted from full-fat CMS flour sample. At the same timeframe, the $\mathrm{AV}$ increased from 1.1 to $6.9 \mathrm{mg} \mathrm{KOH} \mathrm{g}^{-1}$ of oil. However, considering the defatted CMS flour sample, there was very slow degradation, relative to the full-fat sample. UV absorbance sluggishly increased from 0.30 to 0.92 , after $1 \mathrm{yr}$. Although the defatted flour had a characteristic taste and smell slightly different from that of fresh full-fat flour, the defatted flour remained intact over the one-year probation period. The peroxide value increased from $1.7 \mathrm{meq} \mathrm{O}_{2} \mathrm{~kg}^{-1}$ on the 1st day, to $6.1 \mathrm{meq} \mathrm{O}_{2}$ $\mathrm{kg}^{-1}$ after $1 \mathrm{yr}$ of storage. While, the AV increased from 1.1 to $4.3 \mathrm{mg} \mathrm{KOH} \mathrm{g}^{-1}$ of oil, over the same period of time. Full-fat CMS flour would be best consumed as food within $13 \mathrm{~d}$ from the date of preparation, considering the noticeable changes in taste and smell, while for the same purpose, defatted flour can last up to a year, retaining its characteristic taste and smell, without the inclusion of any preservative or food additive. Obviously, CMS flour is better stored in the defatted state, as that reduced both the moisture and unsaturated lipid content, making the flour more biochemically stable; hence, improved shelf life. As a result, the protein-rich food crop can be produced commercially and stored effectively as defatted flour, while its oil finds other relevant applications.

In a study entitled, "Effect of drying method on the quality and storability of 'egusi' melon seeds (Colocynthis citrullus L.)", Bankole et al. [43] report short shelf-life as one major challenge in dealing with melon seeds; noting that the seeds are easily prone to fungal infection which depreciates the nutritional value, increases the peroxide value, while encouraging mycotoxin production. According to ancient works of Harrington [44, 45], unit percentage reduction in moisture content (within the range of 5 to 14\%), has been found to double the lifespan of seeds, while the same seed life is halved for every $5{ }^{\circ} \mathrm{C}$ increase in storage temperature (within the range of 0 to $50^{\circ} \mathrm{C}$ ). The lower moisture content of defatted flour contributed to its relatively higher shelf-life. Flour storage temperature close to $0{ }^{\circ} \mathrm{C}$ would generally improve storability. Unsaturated fatty acid triglycerides, in the presence of moisture, undergo hydrolytic autoxidation to yield FFAs and other oxidation products which raises the peroxide value, while tarnishing the moisture content and IV [41]. For fresh oils, peroxide value falls below 10 meq $\mathrm{O}_{2} \mathrm{~kg}^{-1}$, while for rancid ones, the value lies between 20 and 40 meq $\mathrm{O}_{2} \mathrm{~kg}^{-1}$ of oil [33]. In, "Ascertaining the Shelf-life of Ground Melon Seed (Cococynthis citrullus)", Nwakaudu et al. [41] found that the shelf-life of full-fat C. citrullus seed flour could be inferred based on its purpose - the life of the flour used for soup was up to $18 \mathrm{~d}$, while for the purpose of edible oil, shelf-life was only $2 \mathrm{~d}$.

\section{Performance of $\mathrm{CMO}$ in biodiesel production}

At a fixed catalyst concentration of $5.4 \%$, temperature of $50{ }^{\circ} \mathrm{C}$ and reaction time of $2.5 \mathrm{~h}$, methanol to oil molar ratio was varied from $3: 1$ to $15: 1$. Figure $5 \mathrm{a}$ shows the effect of methanol to oil ratio on $C$. mannii seed oil methyl ester (CMOME) yield. From the figure, increasing the amount of methanol (relative to the amount of oil), from a molar ratio of 3:1 up to 9:1, promoted CMOME yield. A maximum yield of $74 \%$ was reached at a ratio of 9:1. Upon increasing the methanol beyond that ratio, there was diminishing returns on CMOME yield. By stoichiometry, just $3 \mathrm{~mol}$ of alcohol are needed to displace one mol of glycerol in a mol of triglyceride. However, considering the reversible nature of such 

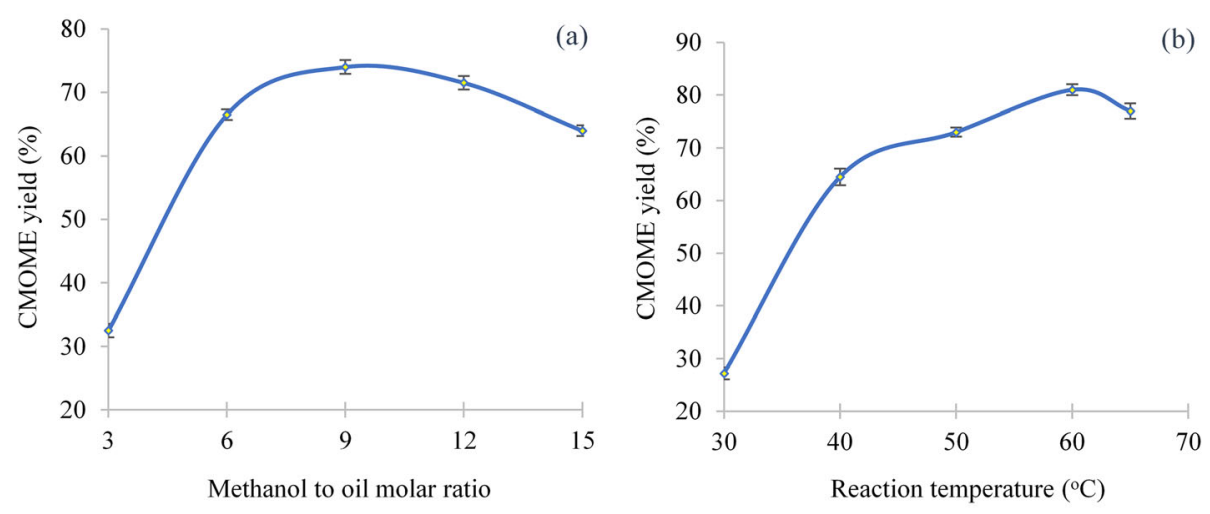

(b)

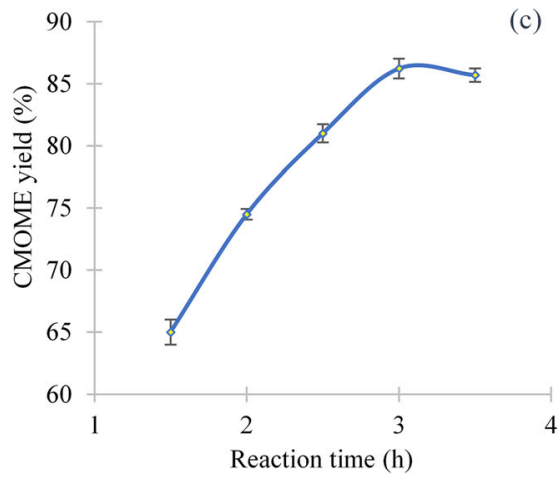

(c)

from duplicated experiments

displacement reaction (transesterification), increasing the concentration of reactant (methanol) would shift the reaction equilibrium in favor of the product (biodiesel). This explains the observed increase in CMOME yield as the methanol to oil molar ratio was increased from 3:1 up to 9:1. The diminishing returns that occurred thereafter could be linked to relatively poor biodiesel recovery, resulting from the co-solvating action of methanol; since methanol is soluble in both biodiesel and glycerol, large amount of methanol in excess of what is needed for reaction, remains residual in the discharged reactor product and deters phase separation during desired product recovery [36, 37].

Also, with a catalyst concentration of $5.4 \%$, methanol to oil molar ratio of 9:1, and reaction time of $2.5 \mathrm{~h}$, the reaction temperature was varied from 30 to $65^{\circ} \mathrm{C}$. The effect of temperature on CMOME yield is shown in Fig. 5b. Upon increasing the reaction temperature, there was a sharp rise in yield (moving from 30 to $40^{\circ} \mathrm{C}$ ), followed by gradual increase up to $77 \%$ at $60^{\circ} \mathrm{C}$. Biodiesel yield began to decline with further increase in temperature. Usually, heterogeneous catalytic reactions of this kind follow more complicated rate steps (rate of mass transfer to and from the catalytic reactive sites becomes as relevant as the chemical reaction rate), unlike the simple homogeneous counterpart; both the mass transfer rate and chemical reaction rate appreciate with temperature [46]. Therefore, at a fixed reaction time, increase in temperature leads to corresponding increase in product yield. This explains the observed rise in CMOME yield below $60^{\circ} \mathrm{C}$. However, at elevated temperatures - above $64^{\circ} \mathrm{C}$, which is about the boiling point of methanol - phase changes could destabilize the catalyst-reactant interaction, thereby reducing reaction effectiveness, and consequently tarnishing product yield.

Furthermore, the influence of reaction time was investigated between 1.5 to $3.5 \mathrm{~h}$, catalyst concentration of $5.4 \%$, methanol to oil molar ratio of 9:1, and reaction temperature of $60^{\circ} \mathrm{C}$. Figure $5 \mathrm{c}$ shows the effect of reaction time on CMOME yield. Increase in reaction time led to progressive increase in biodiesel yield, from $65 \%$ (after $1.5 \mathrm{~h}$ ) to $86 \%$ (after $3 \mathrm{~h}$ ). Afterwards further increase in reaction time slightly reduced the yield. Reaction time is one of the major control parameters for batch processes. The early rise in CMOME yield (in the first $3 \mathrm{~h}$ ) is due to progressive increase in reactant conversion [37]. Now, what possibly could be responsible for the slightly reduction in biodiesel yield, after the third hour? At a point in the course of a catalytic reaction, catalyst could get denatured. Catalyst denaturation 
(not necessarily deactivation) could impede product formation and consequently depreciate yield; otherwise, how do powdered $\mathrm{CaO}$ catalysts come out as pasty lumps/agglomerates after use in transesterification? Prolonged use of the catalyst amidst glycerol leads to calcium diglyceroxide formation [13, 47]. Besides, such trend shown in Fig. 5c is also normal for parallel reaction products in batch reactors and for such reactions, reaction time is crucial in controlling the relative amounts products [46]. Yes, saponification usually occurs in parallel to the desired transesterification [40, 48, 49]; although the undesired soap formation is reasonably mild compared to what is obtainable with homogeneous catalysts [13].

Altogether, CMOME yield of $86 \%$ was the optimum, achieved at catalyst concentration of $5.4 \%$, methanol to oil molar ratio of 9:1, reaction temperature of $60^{\circ} \mathrm{C}$, after $3 \mathrm{~h}$ of reaction. Considering the $1.1 \%$ moisture content of the lipid feedstock (CMO), use of homogeneous/alkali catalyst could have suppressed the CMOME yield due to instantaneous saponification that could consume such catalyst and complicate biodiesel recovery [13, 38]. Bearing in mind that the choice of fatty acid methyl ester (biodiesel) yield model could greatly affect result comparison [38], we hereby highlight the results of some related works. Away with the soap formation (saponification) limitation, biodiesel yield of $86 \%$ is reported for homogeneous acid (sulphuric acid) catalyzed transesterification of CMO [20]. In a similar study with $C$. colocynthis $L$. seed oil and sodium methoxide (acting as homogeneous catalyst), a yield of $82 \%$ was attained at $60{ }^{\circ} \mathrm{C}$, with methanol to oil ratio of $6: 1$ [19]. These works $[19,20]$ employed the most common notion of yield, as criticized in the "Comparative effect of reaction time on biodiesel production from low FAA beef tallow: a definition of product yield" [38]; for they considered biodiesel yield as the percentage mass of biodiesel recovered per mass of oil used.

Lastly, by examining the fuel properties of CMOME (biodiesel) produced at optimum conditions, Table 3 shows the characteristics of CMOME produced at optimum conditions in comparison with literature. From the result of this study, about $97 \%$ of the biodiesel was identified as CMOME by gas chromatographic analysis. The IV still shows high level of fatty acid unsaturation and that suggests that the biodiesel is prone to degrade chemically with time - high IV means poor chemical stability [38]. The cetane index and HHV improved with respect to the CMO feedstock. The high heating value of 42 $\mathrm{kJ} \mathrm{g}^{-1}$ is slightly higher than the $40 \mathrm{~kJ} \mathrm{~g}^{-1}$ reported for biodiesel produced from C colocynthis L. [19], making CMOME a better choice of fuel. The viscosity of CMO was successfully reduced from 31.6 to 4.9 $\mathrm{mm}^{2} \mathrm{~s}^{-1}$, making it an acceptable fuel for conventional diesel engine. The low cold fuel properties: cloud point, pour point and CFPP indicate that the fuel could serve even during winter seasons, in geographic regions where atmospheric temperature does not get to subzero level. A flash point of $173{ }^{\circ} \mathrm{C}$ guarantees safety of the biodiesel fuel for handling and storage. Asides the high IV, the biodiesel resulting from this study met both the European and American biodiesel standards. It also proved to be superior to

Table 3 Characteristics of CMOME produced at optimum conditions in comparison with literature

\begin{tabular}{|c|c|c|c|c|}
\hline & EN-14214 & ASTM D-6751 & [20] & This study \\
\hline Ester content (\%) & $\geq 96.5$ & & & 97.4 \\
\hline Acid value (mg KOH g ${ }^{-1}$ ) & $\leq 0.5$ & $\leq 0.8$ & & 0.21 \\
\hline Density at $15^{\circ} \mathrm{C}\left(\mathrm{kg} \mathrm{m}^{-3}\right)$ & $860-900$ & & 889.9 & 883 \\
\hline Saponification value (mg KOH g ${ }^{-1}$ ) & & & & 132 \\
\hline lodine value $\left[\mathrm{g} \mathrm{I} \mathrm{I}_{2}(100 \mathrm{~g})^{-1}\right]$ & $\leq 120$ & & & 124 \\
\hline Cetane index & & & & 60 \\
\hline High heating value $\left(\mathrm{kJ} \mathrm{g}^{-1}\right)$ & & & & 42 \\
\hline Kinematic viscosity at $40^{\circ} \mathrm{C}\left(\mathrm{mm}^{2} \mathrm{~s}^{-1}\right)$ & $3.5-5.0$ & $1.9-6.0$ & 15.1 & 4.9 \\
\hline Water content $\left(\mathrm{mg} \mathrm{kg}^{-1}\right)$ & $\leq 500$ & $\leq 500$ & & 390 \\
\hline CFPP $\left({ }^{\circ} \mathrm{C}\right)$ & & & & -3 \\
\hline Cloud point $\left({ }^{\circ} \mathrm{C}\right)$ & & & & -2 \\
\hline Pour point $\left({ }^{\circ} \mathrm{C}\right)$ & & & -3 & -3 \\
\hline Flash point $\left({ }^{\circ} \mathrm{C}\right)$ & $\geq 120$ & $\geq 130$ & 155 & 173 \\
\hline Fire point $\left({ }^{\circ} \mathrm{C}\right)$ & & & & 204 \\
\hline
\end{tabular}


the CMOME from a previous study [20], with regards to viscosity and flash point.

\section{Performance of CMO and modified CMO as heavy metal sink in water treatment}

For wastewater treatment application, the contact time sufficient to achieve 2-phase equilibrium was first sought, using a raw $\mathrm{CMO}$ and modified $\mathrm{CMO}$ (TF-CMO) dosage of $3.5 \mathrm{~g}$ in $20 \mathrm{~mL}$ contaminated water. Variation of sorption efficiency for water samples of different contamination levels, based on constant extractant dosage with varying contact time is shown in Fig. 6a. Constant $\mathrm{Ag}_{(\mathrm{aq})}^{+}$concentration was attained after $7 \mathrm{~h}$ using contaminated water of different initial concentrations. In other words, the equilibrium phase contact time was found to be $7 \mathrm{~h}$. With the stated extractant dosage, at equilibrium, the TF-CMO was able to trap/remove/sink 96, 68, 52 , and $42 \%$ of $\mathrm{Ag}^{+}$in $600,900,1200$, and $1500 \mathrm{ppm}$ simulated water, respectively. This simply suggests that at equilibrium, the active sorption sites of TF$\mathrm{CMO}$ were saturated with $\mathrm{Ag}^{+}$, leading to the extraction of virtually the same amount of contaminant, irrespective of initial concentration of the water. Also, from the figure, only the sulphur-modified oil extractant (TF-CMO) was effective in Ag sequestration. Attempts to treat 600 and $1500 \mathrm{ppm} \mathrm{Ag}$ contaminated water using raw $\mathrm{CMO}$, showed no promising results up to $10 \mathrm{~h}$ of phase contacting. Of course, there is no notable interaction between aqueous metallic ions and normal fatty acid triglyceride (organic) phase that could trigger inter-phase transfer of $\mathrm{Ag}^{+}$. As a result, it was verified that thiol functionalization of CMO bestowed on the oil some heavy metal sinking potentials. Earlier reports on similar comparative extraction with oils (derived from corn, soybean, palm fruit and kernel) and their thiol-functionalized equivalents witnessed complete dormancy of unmodified (raw) oil samples [24, 28].

Furthermore, Fig. 6b shows the variation of sorption efficiency for water samples of different contamination levels, based on changing extractant dosage at the established common equilibrium contact time; dotted lines were used because outside the marked points, removal efficiency does not necessarily follow the line-progression. Higher cation sorption efficiency was achieved for every increase in extractant dosage level, at all contaminant concentrations. Although it was not possible to strictly maintain specific dosages due to uncertainty in measuring the mass of liquids, at every dosage level, greater cation removal efficiencies were obtained with lower contaminant concentrations. This is expected if the extractant active sites should be saturated at equilibrium. That does not necessarily mean equal amount of cation removal; because, take for instance, at a dosage of $6 \mathrm{~g}(20 \mathrm{~mL})^{-1}$ of water, efficiencies of: 100, 93, 78, and 54\% were achieved with 600, 900, 1200, and $1500 \mathrm{ppm}$ contaminated water, meaning that: 600, 837, 930, and 806 ppms $\mathrm{Ag}^{+}$were removed, respectively. Indeed, the sorption kinetics of the process deserves to be looked into. The performance of TF-CMO is very promising for it compares well with butanethiol-functionalized corn oil, in the treatment of $600 \mathrm{ppm}$ of $\mathrm{Ag}^{+}$in simulated water [24]. At all contaminant concentrations, moving from zero to a dosage of $1 \mathrm{~g}(20 \mathrm{~mL})^{-1}$ of water, relatively very high removal efficiency was achieved for the little increment in extractant dosage, suggesting that low dosage levels could be more efficient; hence, stagewise operations (employing low extractant dosages per stage) could be more economical (a)

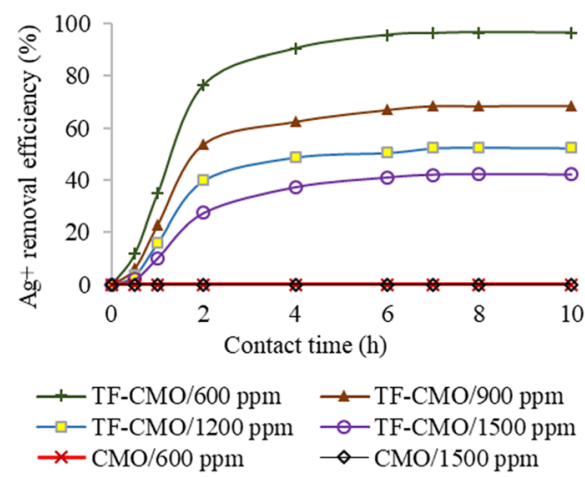

(b)

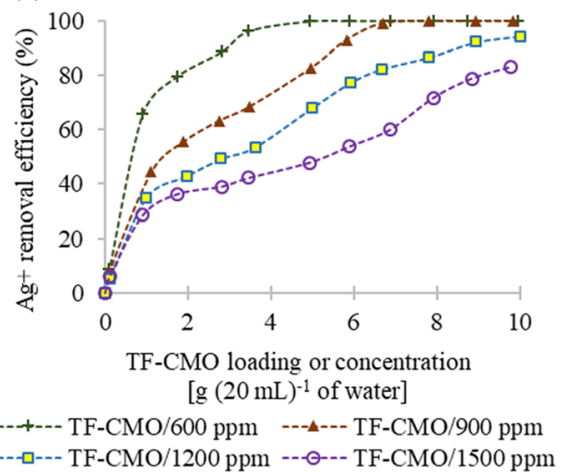

Fig. 6 Variation of sorption efficiency for water samples of different contamination levels, based on: a constant extractant dosage with varying contact time, $\mathbf{b}$ varying extractant dosage at common equilibrium contact time 


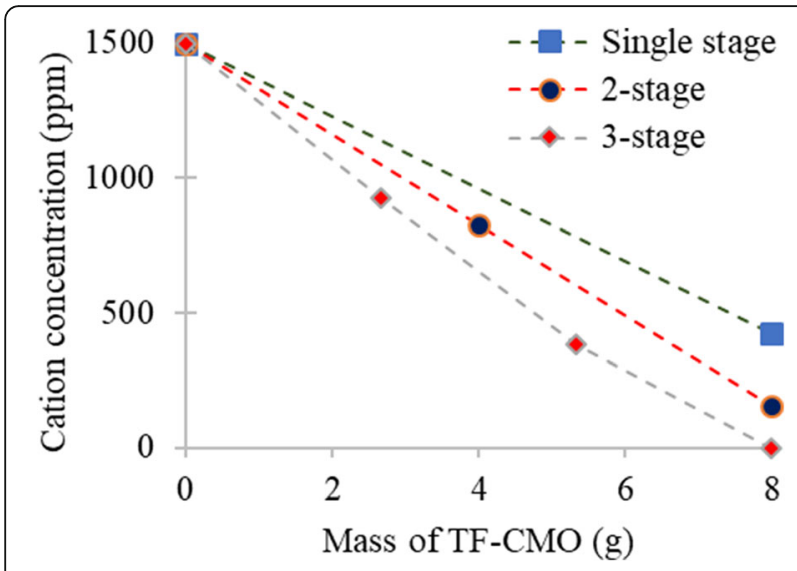

Fig. 7 Comparison of single-stage and multi-stage extraction operations for the treatment of $20 \mathrm{~mL}$ of $1500 \mathrm{ppm}$ simulated water using $8 \mathrm{~g}$ of TF-CMO

(with regards to saving the extractant) for highly concentrated wastewater.

As a result, attempt was made to treat $20 \mathrm{~mL}$ of 1500 ppm simulated water in 2 and 3 stages, using $8 \mathrm{~g}$ of TFCMO split equally for each stage. The reductions in aqueous $\mathrm{Ag}^{+}$concentration is compared for single-stage and multi-stage operations. Figure 7 depicts a comparison of single-stage and multi-stage extraction operations for the treatment of $20 \mathrm{~mL}$ of $1500 \mathrm{ppm}$ simulated water using $8 \mathrm{~g}$ of TF-CMO; dotted lines were used because outside the marked points, concentration does not necessarily follow the line-progression. For the multi-stage operations, the extractant was distributed evenly across the stages. It was possible to reduce the $1500 \mathrm{ppm}$ to: 425,154 and $0 \mathrm{ppm}$, via: single, double and tripple stage operations, respectively; that is to say, the cation removal efficiency of $72 \%$ recorded for single-stage operation, improved to 90 and $100 \%$, by mere multistaging, while maintaining the same amount of extractant split into 2 and 3 parts, respectively. Yes, stagewise operation appears to be attractive with respect to the extratant management, but adequate economic analysis has to consider the extra resources (including time and labour) needed per stage.

\section{Conclusions and recommendations}

In conclusion, this study has successfully demonstrated the fuel and $\mathrm{Ag}^{+}$metal-sinking potentials of a well identified untapped West African seed crop, the C. mannii. CMS was found to possess high expressible-lipid content, with the CMO having high level of fatty acid unsaturation. The reduction in oil content of CMS flour by mechanical expression greatly improves the shelf life of the residual protein meal, and good enough, the defatted protein-rich cake remains available for food.

Considering its use for fuel production, by variation of one experimental factor at a time, a maximum $\mathrm{CMO}$ biodiesel yield of $86 \%$ was achieved using $5.4 \%$ E. vermiculata shell-derived-nanocatalyst, with methanol to oil molar ratio of 9:1, reaction temperature of $60^{\circ} \mathrm{C}$, after 3 $\mathrm{h}$ of transesterification reaction. It can be inferred that $\mathrm{CMO}$ is a good candidate, because, besides the high fuel yield, the CMOME met both the American and European biodiesel standards, except for its poor oxidation stability; however, for amelioration, fuel blending and/or use of additives are recommendable.

On the other side, sulphur-modified CMO exhibited desirable heavy metal liquid-liquid sorption properties. In a single stage operation, $7.8 \mathrm{~g}$ of modified CMO could effectively treat $20 \mathrm{~mL}$ of $900 \mathrm{ppm} \mathrm{Ag}$ contaminated water. Optimization of the process could yield better results. However, the equilibrium contact time of $7 \mathrm{~h}$ is practicably high; further studies should focus on investigating and improving the process kinetics. Stagewise operation is promising in dealing with highly concentrated wastewater samples. Economic consideration would aid in striking balance between extractant savings achieved upon multi-staging, and the extra capital and operating costs necessary for such mode of operation.

Finally, regardless of the food quest, the industrial use of CMO should be encouraged as the defatted residual cake remains edible with improved shelf-life. As the crop gains more applicability, research into its cultivation and management for increased productivity, should proceed in parallel - several aspects to be considered are suggested in "Lost Crops of Africa" [1]. Moreover, the production and utilization of CMS should extend beyond Africa.

\section{Acknowledgements}

The authors acknowledge the support of the Department of Chemical Engineering, University of Benin, Nigeria, during the preliminary experiments. Regards to Chiebuka T. Nnodim for fetching the snail shells. The authors mourn with CJC and CJC for the demise of their ever-supportive mother.

\section{Authors' contributions}

OSO conceived the idea and supervised the entire work. CJC, CJC, and OEM designed and performed experiments (data collection). CJC (John) and EKU provided materials. OSO, CJC (John), PCU and CAO interpreted and discussed the data. CJC, CJC, CAO, EKU and PCU wrote the first draft. All authors read and approved the final manuscript.

\section{Funding}

The authors received no financial support for the research, authorship and publication of this article.

\section{Availability of data and materials}

All data generated or analyzed during this study are available upon request.

\section{Competing interests}

The authors declare they have no competing interests.

Received: 26 June 2020 Accepted: 9 February 2021

Published online: 25 February 2021

\section{References}

1. National Research Council. Egusi. In: Lost crops of Africa: Volume II: Vegetables. Washington, DC: The National Academies Press; 2006. p. 154-71.

2. Blench R. Plants. In: Archaeology, language, and the African past. Lanham: AltaMira Press; 2006. p. 191-242. 
3. FAO. FAOSTAT Data on Crops: Melonseed. Food and Agriculture Organization of the United Nations; 2020

4. Burkill HM. Useful plants of west tropical Africa. 1. Kew: Royal Botanic Gardens, Kew; 1985.

5. Essien EA, Umoren SA, Essien EE, Udoh AP. Preparation and evaluation of Cucumeropsis mannii Naud. seed oil metallic soaps as driers in gloss paint. J Mater Environ Sci. 2012;3:477-84.

6. Azuaga IC, Igbum GO, Kyenge BA. Extraction and characterization of three tropical seedoils: Telfairia occidentalis, Hura crepitans and Cucumeropsis mannii. Chem Res J. 2018:3:1-8.

7. ECHO. Egusi melon. North Fort Myers: ECHOcommunity; 2019

8. Egwim EC, Akanya HO, Onuekwusi EC, Ossamulu IF, Mohammed JM. Physicochemical and organoleptic properties of some selected foods fried with melon (Citrullus Lanatus) seed oil. IOSR J Biotechnol Biochem. 2015;1: 43-8.

9. Fokou E, Achu MB, Tchounguep FM. Preliminary nutritional evaluation of five species of egusi seeds in Cameroon. Afr J Food Agric Nutr Dev. 2004;4. https://doi.org/10.4314/ajfand.v4i1.19151.

10. Taylor O. Seed keeping: the story is in the seed. New York: Tumblr; 2019.

11. Manske M. Egusi_unshelled.jpg. Wikipedia; 2013.

12. Isibor S. Cucumeropsis mannii African melon (egusi). Ovwian: Pebonex Nigeria Limited; 2019.

13. Okwundu OS. Biodiesel production from animal fat using calcium-based catalysts [Master's Thesis]. Alexandria: Egypt-Japan University of Science and Technology; 2019.

14. Opoku-Boahen $Y$, Novick BD, Wubah D. Physicochemical characterization of traditional Ghanaian cooking oils, derived from seeds of egusi (Citrullus colocynthis) and werewere (Cucumeropsis manni). Int J Biol Chem Sci. 2013;7: 387-95.

15. Ogunbusola EM, Fagbemi TN, Osundahunsi OF. Chemical and functional properties of full fat and defatted white melon (Cucumeropsis mannii) seed flours. J Food Sci Eng. 2012;2:691-6.

16. Olubi O, Felix-Minnaar JV, Jideani VA. Physicochemical and fatty acid profile of egusi oil from supercritical carbon dioxide extraction. Heliyon. 2019;5: e01083

17. Ajibola OO, Eniyemo SE, Fasina OO, Adeeko KA. Mechanical expression of oil from melon seeds. J Agr Eng Res. 1990;45:45-53.

18. Muhammad BY, Mariah AN, Othman JB, Yahya A, Bashar ZU. Egusi melon (Citrullus lanatus) crop - Malaysian new oil/energy source: production, processing and prospects. Aust J Crop Sci. 2013;7:2101-7.

19. Giwa S, Abdullah LC, Adam NM. Investigating "egusi" (Citrullus colocynthis L.) seed oil as potential biodiesel feedstock. Energies. 2010;3:607-18.

20. Opoku-Boahen Y, Clemente R, Wubah D. Investigation of Cucumeropsis mannii N. seed oil as potential biodiesel feedstock. Int J Biol Chem Sci. 2013; 7:1767-76.

21. Kinemuchi $H$, Ochiai B. Synthesis of hydrophilic sulfur-containing adsorbents for noble metals having thiocarbonyl group based on a methacrylate bearing dithiocarbonate moieties. Adv Mater Sci Eng. 2018:2018:3729580.

22. Saha D, Barakat S, Van Bramer SE, Nelson KA, Hensley DK, Chen JH. Noncompetitive and competitive adsorption of heavy metals in sulfurfunctionalized ordered mesoporous carbon. ACS Appl Mater Inter. 2016;8: 34132-42.

23. Murray RE, Bantchev GB, Doll KM, Dunn RO, Ascherl KL. Heavy metal remediation via sulfur-modified bio-oils. Geneva: World Intellectual Proerty Organization; 2014

24. Murray RE, Bantchev GB, Dunn RO, Ascherl KL, Doll KM. Thioetherfunctionalized vegetable oils: metal-absorbing biobased ligands. ACS Sustain Chem Eng. 2013;1:562-5.

25. Yantasee W, Warner CL, Sangvanich T, Addleman RS, Carter TG, Wiacek RJ, et al. Removal of heavy metals from aqueous systems with thiol functionalized superparamagnetic nanoparticles. Environ Sci Technol. 2007; 41:5114-9.

26. Mercier L, Pinnavaia TJ. Heavy metal lio adsorbents formed by the grafting of a thiol functionality to mesoporous silica molecular sieves: factors affecting Hg (II) uptake. Environ Sci Technol. 1998;32: 2749-54

27. Dunn RO, Bantchev GB, Doll KM, Ascherl KL, Lansing JC, Murray RE. Thioether-functionalized corn oil biosorbents for the removal of mercury and silver ions from aqueous solutions. J Am Oil Chem Soc. 2018;95:1189-200.
28. Okwundu OS, Enyekwe CK, Chiama CJ, Chiama J, Muojama OE, Okaro CA, et al. Heavy metal sorption using thiolated oils of Elaeis guineensis and Glycine max. Metall Mater Eng. 2020;26:317-27.

29. Krisnangkura K. A simple method for estimation of cetane index of vegetable oil methyl esters. J Am Oil Chem Soc. 1986;63:552-3.

30. Demirbas A. Fuel properties and calculation of higher heating values of vegetable oils. Fuel. 1998;77:1117-20.

31. Stanislaus OO. Processing of fresh cassava tubers into instant noodle food [Bachelor's Thesis]. Benin City: University of Benin; 2014.

32. Efthymiopoulos I, Hellier P, Ladommatos N, Russo-Profili A, Eveleigh A, Aliev $A$, et al. Influence of solvent selection and extraction temperature on yield and composition of lipids extracted from spent coffee grounds. Ind Crop Prod. 2018;119:49-56.

33. FSSAI. Manual on oils and fats. New Delhi: Food Safety and Standards Authority of India; 2015

34. Tangboriboon N, Kunanuruksapong R, Sirivat A. Preparation and properties of calcium oxide from eggshells via calcination. Mater Sci-Poland. 2012;30: 313-22.

35. Okwundu OS, El-Shazly AH, Elkady MF. Investigation of the role of egg membrane in $\mathrm{CaO}$ synthesis and methods for stable composites syntheses. Arab J Sci Eng. 2020. https://doi.org/10.1007/s13369-020-04945-1.

36. Akhabue CE, Okwundu OS. Monitoring the transesterification reaction of castor oil and methanol by ultraviolet visible spectroscopy. Biofuels-UK. 2019;10:729-36.

37. Okwundu OS, El-Shazly AH, Elkady MF, Shaaban WM. Response surface modeling and optimization of heterogeneous methanolysis of beef tallow. AIP Conf. Proc., vol. 2123. AIP Publishing; 2019. p. 020003-1-020003-13. https://doi.org/10.1063/1.5116930.

38. Okwundu OS, El-Shazly AH, Elkady M. Comparative effect of reaction time on biodiesel production from low free fatty acid beef tallow: a definition of product yield. SN Appl Sci. 2019;1:40.

39. Bantchev GB, Kenar JA, Biresaw G, Han MG. Free radical addition of butanethiol to vegetable oil double bonds. J Agr Food Chem. 2009;57: 1282-90.

40. Latchubugata CS, Kondapaneni RV, Patluri KK, Virendra U, Vedantam S. Kinetics and optimization studies using response surface methodology in biodiesel production using heterogeneous catalyst. Chem Eng Res Des. 2018;135:129-39.

41. Nwakaudu AA, Nwakaudu MS, Owuamanam Cl, Alagbaoso SO, Njoku NE, Agunwah IM, et al. Ascertaining the shelf-life of ground melon seed (Cococynthis citrullus). Eur J Food Sci Technol. 2017:5:13-21.

42. Aluyor EO, Okwundu OS. Development of whole cassava based instant noodles. Int J Agric Earth Sci. 2015;1:34-47.

43. Bankole SA, Osho A, Joda AO, Enikuomehin OA. Effect of drying method on the quality and storability of 'egusi' melon seeds (Colocynthis citrullus L.). Afr J Biotechnol. 2005;4:799-803.

44. Harrington JF. Thumb rules of drying seed. Crop Soils. 1960;13:16-7.

45. Harrington JF. Seed storage and longevity. In: Kozlowski TT, editor. Seed biology. New York: Academic Press; 1972. p. 145-245.

46. Levenspiel O. Chemical reaction engineering. 3rd New York: Wiley; 1999.

47. Kouzu M, Hidaka J, Komichi Y, Nakano H, Yamamoto M. A process to transesterify vegetable oil with methanol in the presence of quick lime bit functioning as solid base catalyst. Fuel. 2009;88:1983-90.

48. Yin XL, Duan XL, You QH, Dai CH, Tan ZB, Zhu XY. Biodiesel production from soybean oil deodorizer distillate using calcined duck eggshell as catalyst. Energ Convers Manage. 2016;112:199-207.

49. Prasertsit K, Phoosakul P, Sukmanee S. Use of calcium oxide in palm oil methyl ester production. Songklanakarin J Sci Technol. 2014;36:195-200.

\section{Publisher's Note}

Springer Nature remains neutral with regard to jurisdictional claims in published maps and institutional affiliations. 